\title{
A Review Of Second Language Teaching And Learning Through Short Fiction And Communicative Approach
}

\author{
Dr. Tariq \\ Lecturer in English University of Malakand \\ Mr.Saddam Hussain \\ Lecturer in English University of Malakand \\ Dr. Shaukat Ali \\ Assistant Professor of English, University of Malakand
}

\begin{abstract}
This paper examines the potential role of literature and Communicative Approach in teaching second language (SL). This paper mainly focuses on digging out the prospective role of literature and Communicative Approach in teaching SL. Analysis of past studies indicate that teacher usually recourse to Grammar Translation Method for teaching of English language, for this method needs little endeavor and supplementary materials[1]. The reviewed literature has found that this method is ineffective and futile. To critically examine the potential role of literature in combination with Communicative Approach in teaching SL, this paper tries to unearth the current literature and investigates the relevant research works carried out on the importance of exploiting Literature and Communicative Approach for teaching of English language. The present paper found that using literature and communicative approach for teaching of SL is more effective and productive than GTM. In the light of findings of this study, it is recommended that teachers of L2 need to exploit literature and employ Communicative Approach for teaching of second language.
\end{abstract}

Key Words Communicative Approach, Literature Review, Second Language

\section{Introduction}

Second Language learning takes place outside the native speech community which is both arduous and demanding because L2 learners do not usually have direct access to native environment; and they are often forced to put in extra efforts in the language classroom. But unfortunately, it does not seem to work for native real life environment, because the method of teaching of L2 is based on Grammar Translation Method (GTM), which is more prevalent among SL teachers, for it demands little efforts and resources on the part of teachers (textbooks, a piece of chalk and blackboard). In addition, it is less labor-intensive for teachers and learners; all students are supposed to learn grammar and vocabulary in chunks, and that too in isolation. 
Main focus of this method is on memorization, rote learning and translation from the target language to first language and vice versa. Teaching second language (SL) through this method provides learners with some knowledge about target language but they are unable to communicate, for its focus is not on the communicative aspects of the language rather on the usage of it [2]. Its contents are often limited to school family life, and very rarely involve social and real life, attaching much importance to mastering form rather than practical application of L2. Hence, learning only linguistic elements and grammatical knowledge is not sufficient for L2 learners [3]. Moreover, language learned in this fashion has no utility in real life because it is taught in isolation and units $[4,5]$. For example, teaching L2 through word to word translation and using students' first language for teaching target language [6, 7], does not serve the needs of L2 learners. Teacher is all and all in the class and learners are supposed to get correct answers. The prime objective of this method is to sharpen the skills of the students to read and write at the cost of speaking and listening, with pronunciation almost ignored. Memorization of vocabulary and structure is emphasized at the cost of communicative competence, so students graduating from schools are not competent in communication. Nevertheless, the main purpose of teaching L2 is to improve the communicative competence of learners.

\section{Employing CLT for Learning the Target Language (L2)}

Language teaching and learning is a process of varying aims geographically. The methods and techniques designed for teaching and learning of L2 may work in one context, but may not work in another context due to certain reasons. Thus various methods, techniques and approaches were tried and used for certain period of time, such as (GTM) The Grammar Translation Method and Audio-lingual Method which relies much on structured drills and repetition of drills that makes the process monotonous and the activities boring for the students.

The German Scholarship suggested Grammar Translation Method as the offspring of some leading supporters [8] the goal of which was "to know everything about something rather than the thing itself" [9]. The salient characteristics of this method include:

The sole motive of learning a foreign language is to make an individual capable of reading its literature or to get full advantage from the psychological discipline and the rational growth that affects studying the foreign language. The way of Grammar Translation is to have a detailed examination of its grammar rules, then translating the texts and sentences into and out of the language by the application of the skill acquired. Hence, according to this method language learning is not only understanding the rules and facts but to comprehend and manipulate the syntactic structure and morphology of the second language. As mentioned by [11] "The L1 is determined to be a reference system in acquiring of the second language" (455). 
Conventional language teaching welcomed the increasing interest in CLT approach to teaching foreign language. In this approach, the focus on teaching grammatical rules and units and other linguistics elements shifted to teaching of communicative aspect of language using authentic materials in the language classroom where students take ownership of their learning. On the assumption, that they can use what they learn in the language classroom. This communicative approach and other related approaches appeared such as Audiolingualism, Situational Language Teaching, Total Physical Response, Silent Way Counseling Learning and Suggestopedia appeared in the same period. Apart from these methods and approaches Neurolinguistic Programming and Multiple Intelligences appeared in the language teaching profession. These methods were not considerably developed in the language teaching field because the learning principles of these methods and approaches were different from those available in second language acquisition except vocabulary and lexical phrases that are the building blocks of communicative competence. Methods like Total Physical Response, Silent way counselinglearning, and Suggestopedia did not flourish in the language teaching domain nor attracted the support of the majority of second language teachers. Each of them saw but a brief popularity among language teaching domain and soon disappeared from the sight.

To overcome the lack of communicative competence among L2 learners, the integration of short fictions in SL classrooms seems to be an appropriate option among other materials because it has got a rich potential and authenticity of materials [14]. Short stories with its rich potential and promising nature can easily enhance the learners' four basic skills: listening, speaking, reading and writing [15] Short stories have been singled out on account of their effective, motivational and cultural enrichment [4, 16]. Short stories as a source text in combination with communicative approach have been recommended by scholars for being involving, interesting and authentic. In addition, communicative approach being popular and practical for giving much importance to the use of authentic materials used in real life situations [16, 21], for teaching L2.

Moreover, English language teachers have reckoned that literature can be utilized up to a maximal level to strengthen the four basic skills, and to improve language teaching as well [22, 23]. [24, 25] assert that with learners at the beginning and intermediate levels, teachers can utilize literature for "language utilization, reading comprehension, and aesthetic value of the text". [26, 27] in contrast, with the students of advanced level, "literary texts" are bound to be utilized for "knowledge development globally in the realms of literature such as identifying figures of speech, layers of meaning, and other discursive elements" Moreover, students gain insight and motivation by getting entry into literature. They will explore the world of familiar or unfamiliar cultural aspects of stories [28], compels them to think outside the box.

\section{The Role of Short Fiction in Teaching and Learning of Second language}


Literature not only provides authentic materials but also introduces the learners to the target language culture which can prove positive in term of learners' positive attitude towards target language community [23,29,30]. Literature carries the norms, values and ethos of the target community which has inevitable "penetrative and pervasive" effect on the minds of the learners [31]. Literature familiarizes L2 learners with the true nature of the target language, how much it is flexible and elastic that native speakers bend it to meet their needs, or adapt to new situations. Apart from "authentic materials", short story gives two characteristics, one language in use, meant for native speakers without any modification to its linguistic elements.[32]

Second an aesthetic value of language in spoken form which is supposed to recover or represent language within a specified sphere of cultural context [33,34]. Short stories are not written without their contexts. They always happen in certain cultural contexts which represent certain segments of a given society. It also penetrates through the static nature of language established by artificial grammar of classroom being modified and artificially reconstructed where the learners communicate but at a survival level.

Language enrichment, be it either through aesthetic sense or through active reading of literary work, provides a "rich context in which individual or lexical items are made more memorable". $[36,37]$. Despite this fact, it also makes a connection with literary work which further exposes learners to the formation and functions of sentences, improves their speaking and writing skills. It also enriches their repository of words as finding of words is often followed by looking up cultural references, and cultural enrichment, Justice [38]. As rightly defined by [39] that Literature as a source of authentic materials, where learners are exposed to the language that is genuine and undistorted in the classroom context.

\section{How Literature Helps in Teaching and Learning of Second Language?}

There are different ways in which this goal could be achieved. These ways have been presented below.

\section{Reinforcement and Benefits of Short Stories}

Several benefits of short stories teaching for the purpose of teaching L2/EFL have been advocated by the researchers. They are; literary, motivational and cultural benefits that pave the way for instructors to reinforce the skills through them.

\section{Reinforcing the skills}

Language proficiency at any level is enriched by incorporating short stories and the teachers are facilitated to teach basic language skills through them [4] shows that "short stories will give an edge to ELT courses for learners if the quality text content is appropriately exploited and 
selected". He explicates the reasons for which stories should be used for reinforcing the ELT. Instructors can plan and create activities such as drafting, letters, applications and essays to various audiences and on different topics as well as implementing acting dialogues. Also, [40] states that literature assists learners to write creatively and critically.

For Example, students can be given tasks to write dialogues in the classes $[4,41]$ or to write with strenuous efforts complex writing activities provided that the students have achieved proficiency level of language. Likewise, a literary work provides a "rich context" in which individual or lexical items are made more memorable, and gives learners a clear view of looking into syntactic structure of the text and they properly analyze the way how to differentiate written language from spoken.

Language is beyond the realms of words for it is the repository and means of habits, routines, traditions and socio-cultural context. And above all, when mastered through literature, it can reflect the human soul $[42,43]$. As argued by $[45,46]$ that "Literature increases all linguistic skills as the scope of literature will extend linguistic understanding". The employment of literature and culture in a language classroom should not be randomly selected. Teaching of both disciplines is not akin to transmission of information about the people of a target community [47].

Absorbing the culture of target language needs acumen to focus on the aesthetic reading of the text and find the relation between the text and target language. This kind of relation is a kind of constructing and reconstructing the values in their specific spheres. It motivates the learners to look at the syntactic structure of the text and to differentiate between a written and spoken language.

Linguistic input is densely found in literary text that offers plethora of information regarding the basic language skills. Besides, literary texts help the learners to have know-how of their culture. Further, literary tet deals with universal themes of love, war and other related emotions that persist in humans everywhere. Such themes are not covered in the course books of Second language learners. In this regard, "Literary texts are representational rather than referential" [19, 48]. Referential language does permeate to other levels rather it is mono level language that deals with only one level, whereas the representational language carries other cognitive faculties. It involves the learners' engagement and a pivotal role is given to their emotions. In this way, the students become able to use various devices in literary text.

There are certain objections as to the complexity of literature for teaching foreign language but according to [49], the linguistic difficulties pertaining to literature have been deliberated umpteen times for which readers are not supposed to experience comprehension completely 
rather they are required to gain something or a gist of the text. This is the true nature of literature where connotative interpretation will suffice the purpose rather than denotative meanings [50].

\section{Benefits of Short Stories}

A number of reasons and advantages of using literature in language teaching classroom have been presented by various authors such as,[51] by listing the following with less or more endorsement.

1. Cultural amelioration, by reading literature one can promote one's awareness and understanding with target language community and thus reduces the intensity of cultural shock, $[52,53]$.

2. Linguistic Expression, literature is composed of diverse writing techniques and expressions. It provides learners with distinctive writing styles.

3. Mental training, literature being the creation of sublime and great minds among other disciplines builds and trains readers' sensibility and moral sense.

4. Literature extends readers' linguistics competence, especially of those who have already mastered the basics of linguistics.

5. Reliability on the materials of literature are genuine and authentic for teaching purpose [54].

6. Using literature in language teaching is useful because of the facts that the language used in it is taken from real life situations.

7. Being Interpretive and suggestive, it is open to multiple interpretations and a useful and convenient resource. [17].

Literature stimulates discussion and interaction because it is rich in having multiple levels and shades of meanings, and interpretation, which can easily be exploited by learners. It enhances learners' awareness of the target language obliging them to analyze standard and non-standard usages of language occurred in literary texts. Moreover, it makes their awareness more subtle and analytical of the norms of language use [55, 56]. Apart from its motivating quality, it enjoys an elevated and high position in many cultures and countries, so learning or understanding a piece of highly respected literature can give the learners a sense of achievement. It is involving because it keeps the learners in suspense as what will happen next, on the basis of what has just happened. The instant difficulty with its linguistic elements (lexicons) may not cause any hurdle in the way of understanding and comprehending the theme. 


\section{Importance of Incorporating Short Stories in Teaching of Second Language}

Short stories are the real assets for enhancing the communicative skills of the learners through a developed ration of sensibility and empathy. It serves the purpose of a true and enhanced motivator for the learners to acquire "capacity". It also helps the learners' negotiation and interpersonal skills that are of paramount importance in the global business context. [60]. According to [61] optimal input is apt in acquiring language that is quite relevant and interesting. Short stories grab students' attention and motivation to learn [62] recommends that literature helps students to go beyond mere knowing the basic knowledge of language to "Learning about"| language. In this way, students develop a fifth skill that is the skill of thinking and processing.

The correct use of literary text in classroom aims at improving communicative competence and provide "an edge for uplifting critical thinking and creative aesthetic appreciation" [63, 64], and create students awareness about the sociocultural set up of the target language. For example, the results of some studies, like those of [55] recommend the merging of literary skill in the SL/FL curriculum. Likewise, several writing on this subject propose curriculum which focuses on the context of literature [65, 66]. Short fiction is a source for knowing life other than linguistic faculty. In short stories, a realistic picture of real life is cascaded by the characters who act out real and symbolic aspects of life. This representation takes place in a tone of register and various tones. Short fiction illuminates human lives and it is true representation of humans [6]. The following educational benefits can be attained by the incorporation of short stories fiction the ESL / EFL curriculum [67]. Short story makes reading easier for learners because they are short and easy to understand as compared to other literary books. It opens a way for the learners to use their minds creatively. It also uplifts the critical thinking skill of the students. It also promotes the students ability to communicate with each other because of its universal language. Advanced level learners observe the characters in short fiction that how they make use of linguistic items and figures of speech. These figures have communicative intent which gives an edge to learners to use English clearly and powerfully [68].

\section{Reinforcing the Productive (speaking and writing) Skills}

Short stories enable the learners to gain the language skills proficiently. [69] indicates that "short stories provide authentic and quality text if selected and exploited appropriately that enhances ELT course up to maximal level" (p. 9). This will in turn improve the skills of students at intermediate level. He further asserts that the reasons for reinforcing ELT and adds that teachers can create opportunity for the learners by discussing the activities; in return the learners start acting out the role of characters in the story. In this way they are able to write the themes and perform creatively. In the same vein, [35] confirms, "Literature opens new vistas of experience if the point of view of short fiction is Focused on which enlarges students' horizon of vision and 
fosters critical thinking by orchestrating the several paths through which a situation can be visualized" (p. 85). Therefore, when the learners start reading they hook up with the text. This interaction with the text enables them to interpret what they read. And once the stage of interpretation takes place, they can focus towards speaking English creatively.

\section{Motivating Aspect of Short Story}

Short stories have plot construction in a streamlined form as they have beginning, middle and the end. This triggers the linguistic proficiency of the students at all levels. Their ability of cognitive reasoning is stimulated while reading the text of short story as they find out the rise of conflict then its climax and resolution. [71] for example, affirms that "literature motivates advanced students and is motivationally effective if students can genuinely engage with its thoughts and emotions and appreciate its aesthetic qualities" (p. 197). He insists on the importance of developing "student-response and competence" in literature. In addition, there is a reason [72] asserts for employing literature with learners is that "literature motivates students to explore their feelings through experiencing the feelings of others" (p. 1).

In addition, choosing stories according to students' preferences, stories ought to have density of themes because, as [73] point out, variety of themes will offer different things to many individuals' interests and tastes (p.178). Teachers are supposed to teach elements with simplicity and lucidity to intermediate level students as character, plot construction and setting become difficult for them to understand. Whereas more complex elements, such as conflict, climax, resolution, etc., should not be taught to intermediate level rather they should be introduced with more advanced levels. [74] explains "how literature can be introduced by describing the order of activities: pre-reading activities, factual in-class work, analysis and extending activities". In the pre-reading activities, students learn the background of the story and they come to know about the vocabulary of the story (p. 233).

Besides the basic language skills, short stories assist instructors in teaching literary, cultural and higher-order thinking aspects. As for culture and other related benefits, [75] believe that culture should be intermingled with curriculum and "literature is one feature . . . in the cultural domain that provides added value beyond the level of language acquisition." Literature helps students in expanding their "linguistic and cognitive skills, cultural knowledge and sensitivity" (quoted in [20]. One is led to say that integrating short stories into the curriculum will help EFL students to become well rounded professionals and human beings, for short stories teach more than the skills necessary for survival in the target language.

Students also become more productive and daring once they come to know the richness and flexibility of the language they are learning and set about to make use of some of that potential without any external support. Thus, knowing the meanings of individual lexical items or phrases 
becomes less significant than chasing the development of the story. Student becomes enthusiastic to find out what happens as events unfold; he/she feels close to some of the characters in the story. This can have favorable effects on the language learning process.

As pointed by $[74,76]$, that Literature in second language classrooms provides students with opportunities in acquiring competence in L2 like that of native speakers, enabling them to learn the features of modern English as well as linguistic system such as idiomatic expressions. [77] explicates that literature opens up new vistas of possibility that allow students to question, interpret, connect, and explore. In a nutshell, literature provides students with an incomparably dense source of authentic material over a wide range of registers. If students can gain access to this material by developing literary competence, then they can effectively internalize the language at a high level $[63,64]$. Especially, for students with verbal linguistic intelligence, the language teacher's using literature in a foreign language class serves for creating a highly motivating, amusing and lively lesson.[78], Literature does not only develop basic language skills of the students in target language but it also windows opening into the culture of the target language, uplifting cultural competence in students.

\section{Conclusion}

Based on the above discussion it can be concluded that using literature and communicative approach for teaching of second language is highly effective. A large body of knowledge on the use and importance of Communicative Approach and literature also supports this contention as is mentioned above. In this regard many studies have found that teachers can effectively use Communicative Approach as a teaching tool to teach second language. In the same way, many studies also indicated that using short stories (literature) can highly be beneficial for teaching and learning of second language. Based on the analysis done in this paper, it can easily be inferred that communicative Approach and literature can be an effective sources for teaching and learning of second language.

\section{References}

1. Khan, H.I., English teachers' perceptions about creativity and teaching creative writing in Pakistan. American International Journal of Contemporary Research, 2012. 2(3): p. 57-67.

2. Hişmanoğlu, M., Teaching English through literature. Journal of Language and Linguistic Studies, 2005. 1(1).

3. McKay, S.L., Teaching English as an international language: Rethinking goals and perspectives. NY: OUP, 2002.

4. Murdoch, G., Exploiting well-known short stories for language skills development. IATEFL LCS SIG Newsletter, 2002. 23: p. 9-17. 
5. Meraji, S.M. and F. Sadighi, Relation between reading short stories and the writing proficincey of Iranian EFL learners \International Journal of Language Learning and Applied Linguistics World, 2013: p. 134.

6. Sage, H., Incorporating Literature in ESL Instruction. Language in Education: Theory and Practice, No. 66. 1987: ERIC.

7. Kim, H.-R., Literature circles in EFL curricula: Establishing a framework. The English Teacher, 2003. 32: p. 2003-1.

8. Richards, J.C. and T.S. Rodgers, Approaches and methods in language teaching. 2014: Cambridge University Press.

9. Chang, S.-C., A contrastive study of grammar translation method and communicative approach in teaching English grammar. English Language Teaching, 2011. 4(2): p. p13.

10. Ellis, N.C., Implicit and explicit knowledge about language, in Encyclopedia of language and education. 2008, Springer. p. 1878-1890.

11. Stern, H.H., Fundamental concepts of language teaching: Historical and interdisciplinary perspectives on applied Linguistic research. 1983: Oxford University Press.

12. Ellis, R., Grammar teaching-practice or consciousness-raising. Methodology in language teaching: An anthology of current practice, 2002: p. 167-174.

13. Ellis, R., Current issues in the teaching of grammar: An SLA perspective. Tesol Quarterly, 2006. 40(1): p. 83-107.

14. Erkaya, O.R., Benefits of Using Short Stories in the EFL Context. Online Submission, 2005. 8.

15. Khatib, M. and S.H. Seyyedrezaei, Short Story Based Language Teaching (SSBLT): A literature-based Language Teaching Method.

16. Mourao, S., Using stories in the primary classroom. BritLit: Using literature in EFL classrooms, London, 2009.

17. Sivasubramaniam, S., Promoting the prevalence of literature in the practice of foreign and second language education: Issues and insights. Asian EFL journal, 2006. 8(4): p. 254-273.

18. O'Sullivan, R., Literature in the language classroom. The English Teacher, 1991. 20: p. 5-25.

19. Babaee, R. and W.R.B.W. Yahya, Significance of Literature in Foreign Language Teaching. International Education Studies, 2014. 7(4): p. p80.

20. Shanahan, D., Articulating the relationship between language, literature, and culture: Toward a new agenda for foreign language teaching and research. The Modern Language Journal, 1997. 81(2): p. 164-174. 
UNIVERSITY OF CHITRAL JOURNAL OF LINGUISTICS AND LITERATURE

VOL. 3 | ISSUE I | JAN - JUNE | 2019

ISSN (E): 2663-1512, ISSN (P): 2617-3611

21. Pathan, M.M. and Z.E.M.e. Al-Dersi, Investigating the Role of Short-Stories in Overcoming the Problems Faced by the Libyan EFL Learners in Reading Comprehension Skill.

22. Kirkgöz, Y., Incorporating short stories in English language classes. Novitas-ROYAL (Research on Youth and Language), 2012. 6(2): p. 110-125.

23. Premawardhena, N.C., Integrating literature into foreign language teaching: A Sri Lankan perspective. Novitas-Royal, 2005. 1(2): p. 92-97.

24. Baker, L., Opportunities at home and in the community that foster reading engagement. Engaged reading: Processes, practices, and policy implications, 1999: p. 105-133.

25. Scarborough, H.S. and W. Dobrich, On the efficacy of reading to preschoolers. Developmental review, 1994. 14(3): p. 245-302.

26. Muyskens, J.A., Teaching Second-Language Literatures: Past, Present and Future. The Modern Language Journal, 1983. 67(4): p. 413-423.

27. Belcher, D. and A. Hirvela, Literature and L2 composition: Revisiting the debate. Journal of second language writing, 2000. 9(1): p. 21-39.

28. Pardede, P. Short stories use in language skills classes: Students" interest and perception. in The Proceeding. 2010.

29. Engelbert*, S., 'Intercultural Training'in exchange situations for experts and management: a critical reflection. Intercultural Education, 2004. 15(2): p. 195-208.

30. Kim, M., Literature discussions in adult L2 learning. Language and Education, 2004. 18(2): p. 145-166.

31. Bilal, H.A., et al., Developing Second Language Reading Comprehension through Short Story. Journal of Literature, Languages and Linguistics, 2013. 1: p. 26-31.

32. Pathan, M.M., Advantages of Using Short-stories in ELT Classroom and the Libyan EFL Learners' Perceptions towards them for Developing Reading Comprehension Skill. Arab World English Journal, 2013. 4(1).

33. Hocaoğlu, M., Developing cultural awareness through the use of literature in language teaching and an examination of cultural aspects presented in certain literature books. 2009, YTÜ Eğitim Fakültesi Yabancı Diller Eğitimi Bölümü İngiliz Dili Eğitimi Lisans Bitirme Tezi. Tez Danışmanı: Dr. Celile Eren Ökten.

34. Chiang, M., Improved reading attitudes and enhanced English reading comprehension via literature circles. Lagos Papers in English Studies, 2007. 1(1): p. 168-183.

35. Oster, J., Seeing with different eyes: Another view of literature in the ESL class. Tesol Quarterly, 1989. 23(1): p. 85-103.

36. Long, M.H. and P.A. Porter, Group work, interlanguage talk, and second language acquisition. Tesol Quarterly, 1985. 19(2): p. 207-228. 
37. Manzo, A.V., U.C. Manzo, and M.M. Thomas, Rationale for systematic vocabulary development: Antidote for state mandates. Journal of Adolescent \& Adult Literacy, 2006. 49(7): p. 610-619.

38. Justice, L.M., J. Meier, and S. Walpole, Learning New Words From StorybooksAn Efficacy Study With At-Risk Kindergartners. Language, speech, and hearing services in schools, 2005. 36(1): p. 17-32.

39. Collie, J. and S. Slater, True to Life Elementary Teacher's Book: English for Adult Learners. 1995: Cambridge University Press.

40. Khatib, M., S. Rezaei, and A. Derakhshan, Literature in EFL/ESL classroom. English Language Teaching, 2011. 4(1): p. p201.

41. Dixon-Krauss, L., Using literature as a context for teaching vocabulary. Journal of Adolescent \& Adult Literacy, 2001: p. 310-318.

42. Kim, H.-R., Making Connections from Language Learning to Life Experiences Through Literature-Based EFL Instruction. English Teaching, 2013. 68(1).

43. Muhammed, A.A., The Effect of Teaching Literature on Learning English Language: A Study on EFS (English as a Foreign Students) and EFL Classes.

44. Widdowson, H.G., Talking Shop: On Literature and ELT. elt Journal, 1983. 37(1): p. 3035 .

45. Widdowson, H.G., Stylistic analysis and literary interpretation. Ching MKL, Haley MC, Lundsford RF Linguistic perspectives on literature. London, 1980.

46. Aghagolzadeh, F. and F. Tajabadi, A Debate on Literature as a Teaching Material in FLT. Journal of Language Teaching and Research, 2012. 3(1): p. 205-210.

47. Cruz, J.H.R., The role of literature and culture in English language teaching. 2010.

48. Rai, A., Use of Literature in Teaching English. International Journal of Educational Research \& Technology, 2012. 3(3).

49. Povey, J.F., Literature in TESL programs: The language and the culture. Tesol Quarterly, 1967. 1(2): p. 40-46.

50. Brett, A., L. Rothlein, and M. Hurley, Vocabulary acquisition from listening to stories and explanations of target words. The elementary school journal, 1996: p. 415-422.

51. Parkinson, B. and H.R. Thomas, Teaching literature in a second language. 2000: Edinburgh University Press Edinburgh.

52. Collie, J. and S. Slater, Literature in the language classroom: A resource book of ideas and activities. 2004: Ernst Klett Sprachen.

53. Ghosn, I.K., Four good reasons to use literature in primary school ELT. elt Journal, 2002. 56(2): p. 172-179.

54. Brumfit, C., Language and literature teaching: from practice to principle. 1985: Pergamon. 
55. Lazar, G., Literature and Language Teaching; Exploring Literary Texts With the Language Learner. Tesol Quarterly, 1996. 30(4): p. 773-776.

56. Widdowson, H.G., Stylistics and the Teaching of Literature. 1975.

57. Krashen, Second language acquisition and second language learning. 1981: Oxford University Press.

58. Tomlinson, B., A multi-dimensional approach to teaching English for the world. English in the world: Global rules, global roles, 2006: p. 130Á150.

59. Willis, J. and D. Willis, Challenge and change in language teaching. 1996: MacMillan Heinemann English Language Teaching.

60. Nieragden, G., Focalization and narration: theoretical and terminological refinements. Poetics Today, 2002. 23(4): p. 685-697.

61. Krashen, Principles and practice in second language acquisition. 1982: Oxford Pergamon.

62. Carter, Literature and language teaching 1986-2006: A review. International Journal of Applied Linguistics, 2007. 17(1): p. 3-13.

63. Elliott, G., Althusser: a critical reader. 1994.

64. Bretz, M.L., Literature and communicative competence: A springboard for the development of critical thinking and aesthetic appreciation. Foreign Language Annals, 1990. 23(4): p. 335-338.

65. Liddicoat, A.J., Teaching languages for intercultural communication. 2005, Federation Internationale des Professeurs de Langues Vivantes.

66. Levy, M., Culture, culture learning and new technologies: Towards a pedagogical framework. Language Learning \& Technology, 2007. 11(2): p. 104-127.

67. Arığul, S., Understanding foreign language teachers' practical knowledge: What's the role of prior language learning experience? Journal of Language and Linguistic Studies, 2007. 3(1).

68. Boughey, C., Multiple metaphors in an understanding of academic literacy. Teachers and Teaching: theory and practice, 2000. 6(3): p. 279-290.

69. Pardede, P., Using short stories to teach language skills. Journal of English Teaching, 2011. 1(1): p. 14-27.

70. Lao, C.Y. and S. Krashen, The impact of popular literature study on literacy development in EFL: More evidence for the power of reading. System, 2000. 28(2): p. 261-270.

71. Shang, H.-f., Content-based instruction in the EFL literature curriculum. The Internet TESL Journal, 2006. 12(11).

72. Vandrick, S., The role of hidden identities in the postsecondary ESL classroom. Tesol Quarterly, 1997.31(1): p. 153-157.

73. Akyel, A. and E. Yalçin, Literature in the EFL class: A study of goal-achievement incongruence. elt Journal, 1990. 44(3): p. 174-180. 
74. Gajdusek, L., Toward wider use of literature in ESL: Why and how. Tesol Quarterly, 1988. 22(2): p. 227-257.

75. Henning, S.D., The integration of language, literature, and culture: Goals and curricular design. Profession, 1993: p. 22-26.

76. Fecteau, M.L., First-and Second-Language Reading Comprehension of Literary Texts. The Modern Language Journal, 1999. 83(4): p. 475-493.

77. Custodio, B. and M.J. Sutton, Literature-Based ESL for Secondary School Students. TESOL Journal, 1998. 7(5): p. 19-23.

78. Ruiz-Funes, M., Writing, Reading, and Reading-to-Write in a Foreign Language: A Critical Review. Foreign Language Annals, 1999. 32(4): p. 514-526.

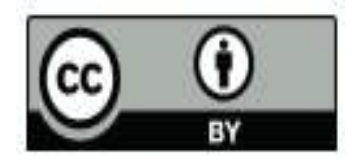

@ 2017 by the author. Licensee University of Chitral, Journal of Linguistics \& Literature, Pakistan. This article is an open access article distributed under the terms and conditions of the Creative Commons Attribution (CC BY) (http://creativecommons.org/licenses/by/4.0/). 